\title{
EXPERIENCE IN CLINICAL APPLICATION OF CRYOPRESERVED PLACENTAL DERIVATIVES: CELLS, TISSUE, MEMBRANES, EXTRACT, AND CORD BLOOD SERUM
}

\author{
V.Yu. Prokopyuk ${ }^{1,2^{*}}$, V.G. Karpenko ${ }^{3}$, M.V. Shevchenko ${ }^{1}$, R.A. Safonov ${ }^{3}$, \\ N.M. Pasieshvili ${ }^{3}$, V.V. Lazurenko ${ }^{3}$, O.S. Prokopyuk ${ }^{1}$ \\ ${ }^{1}$ Institute for Problems of Cryobiology and Cryomedicine of the National Academy of Sciences of Ukraine, Kharkiv, Ukraine \\ ${ }^{2}$ State Enterprise "Interdepartmental Research Center of Cryobiology and Cryomedicine" of NAS of Ukraine, Academy of Medical \\ Sciences of Ukraine and Ministry of Health of Ukraine, Kharkiv, Ukraine \\ ${ }^{3}$ Kharkiv National Medical University of the Ministry of Health of Ukraine, Kharkiv, Ukraine \\ *Corresponding author: v.yu.prokopiuk@gmail.com
}

Received 8 August 2020; Accepted 6 September 2020

Background. The human placenta is a promising source of biomaterial for regenerative medicine. This is primarily due to the availability of a sufficient amount of material, low immunogenicity, a large number of stem cells, and high proliferative cell potential. The effectiveness of stem cells, their lysates, and conditioned media in various pathological conditions has been proven in many studies. Most studies are experimental, or are in different phases of clinical trials. At the same time, in Ukraine there is a wealth of experience of clinical using the cryopreserved placenta medico-immunobiological preparations, which can be the basis for further application of placental material.

Objective. We aim to perform a critical analysis of data on the effectiveness and prospects of application of the cryopreserved placenta preparations (cells, tissues, membranes, extract and cord blood serum) in clinical practice.

Methods. The results of clinical application of 2,579 medical immunobiological Platex and Cryocell placenta preparations were analyzed. An attention was paid to the effectiveness, course of concomitant, comorbid pathology in patients, as well as the presence of negative responses and complications. The number of the preparations used and the one of the patients according to the nosological forms were counted.

Results. The experience of application of medical immunobiological preparations of placental origin in obstetric-gynecological, therapeutic, neurological and endocrinological pathologies is analyzed in the work. The obtained data are compared with the research results in the corresponding model experiments of in vitro and in vivo systems. The positive effect of placental preparations on the course of miscarriage, climacteric syndrome, infertility, diabetes mellitus, coronary heart disease, multiple sclerosis, amyotrophic lateral sclerosis, trophic ulcers has been determined. Contraindications for placenta preparations are some malignancies and an infectious disease process without proper pathogen elimination.

Conclusions. Cryopreserved placenta preparations are effective when used in obstetric, gynecological, neurological, endocrinological and therapeutic practice. Their effect is primarily observed in diseases, which are accompanied by autoimmune reactions, hormonal disorders, dysplastic or degenerative processes. The restricted application of placenta preparations is infectious disease process without proper pathogen elimination.

Keywords: cell therapy; tissue therapy; placenta; biobanking; regenerative medicine; stem cells.

\section{Introduction}

The human placenta is a potential source of biologically active substances and cells for regenerative medicine due to the availability of a sufficient amount of material, low immunogenicity, high proliferative cell potential [1-3].

The current medicine and biology state-ofthe-art allows the involvement of biologically active molecules and cells, which are ontogenetically closer to the human body compared with synthetic and plant compounds. This has led to an increased interest in regenerative medicine, stem cells and their derivatives. The publications describe both clinical and experimental use of placenta derivatives in various fields of medicine: in therapy, surgery, endocrinology, obstetrics and gynecology, ophthalmology, neurology, dermatology, urology, orthopedics, traumatology and others [3-7].

In Ukraine, over the past 100 years, there is a wealth of experience of using the placenta preparations, ranged from the devitalized to stem cell products. These studies have been carried out at the base of The Filatov Institute of Eye Diseases and Tissue Therapy in Odessa, the Institute of Endocrinology and Organotherapy and the Institute for Problems of Cryobiology and Cryomedicine in Kharkiv [8, 9]. In the world, the use of placenta products has come a long way from extracts, devitalized structures, secretions, lysates to cell and tissue preparations. Along with this, many of them also have similar effects [3]. 
From 2006 to 2013, two groups of cryopreserved medico-immunobiological preparations (MIBP), namely the Platex (certificate of the Ministry of Health No. 734/08-300200000) and Cryocell (certificate of the Ministry of Health No. 604/06300200000) were registered and successfully used in Ukraine. Due to low-temperature storage and minimal influence of physical and chemical factors, the Platex and Cryocell MIBP contain a number of tissues, cells and factors inherent the placenta and placental stem cells.

The group of the Cryocell preparations consists of the products of cryopreserved cord blood serum (Cryocell-cryocord), the products from cryopreserved nucleated cord blood cells in cord blood plasma (Cryocell-hemocord), products from cryopreserved nucleated cord blood cells (Cryocellhemocells) and placental extract (Cryocell-cryoextract of placenta). Platex preparations are a set of structural elements of placental tissue (Platex Placental), chorion (Platex Chorional), chorionic and amniotic membrane (Platex Chorionic, Platex Amniotic).

In clinic, the MIBP are prescribed in a combined therapy as a therapeutic and prophylactic immunocorrective agent in cardiovascular pathology, neuroendocrine syndromes, retardation and premature aging, pathological menopause, infertility, asthenovegetative syndrome (to stimulate reparative processes), chronic fatigue, fetoplacental Diabetes mellitus, miscarriage [8,9].

Despite a large number of the drugs used and preclinical research studies, no integrative analysis of the placental MIBP use effectiveness (taking into account the side effects) was carried out. This work will clarify the indications, contraindications and effectiveness of placental MIBP application [8, 9].

The aim of the work was to perform a critical analysis of data on the effectiveness and prospects of application the cryopreserved placenta preparations (cells, tissues, membranes, extract and cord blood serum) in clinical practice.

\section{Materials and methods}

The results of clinical use of 2,579 medical immunobiological Platex and Cryocell preparations were analyzed. The preparations were used according to the instructions. For this purpose, we analyzed disease histories and annual reports of the Medical Center of the Interdepartmental Research Center of Cryobiology and Cryomedicine NAS of Ukraine, the Academy of Medical Sciences, the Ministry of Health of Ukraine and its branches. At the same time, an attention was paid to the effectiveness, course of concomitant, comorbid pathology in patients, as well as the presence of negative responses and complications. The number of the preparations used and the one of the patients according to the nosological forms were counted.

\section{Results}

Analyzing the ratio of the number of different MIBP, used for therapeutic and prophylactic purposes in 1,890 patients, the following results were obtained. Among 2,579 placental MIBP 1,509 Platex MIBP and 1,070 Cryocell MIBP were used in clinic. Table 1 demonstrates the quantitative distribution of MIBP use in clinic.

Table 1 shows that the most commonly used MIBP was Platex Placental, applied to 1,223 patients $(64.7 \%)$. This can be explained by the fact that Platex Placental is a cryopreserved fragment of placenta, and among other MIBP, it most fully retains the placenta combined effect, has the longest withdrawal period of biologically active substances and is relatively simple and cheap to be produced and applied [8]. Cryocell-cryoextract of placenta $(21.1 \%)$ and Cryocell-cryocord $(10.3 \%)$, having the same advantages as Platex Placental, were used in a significant percentage relative to the total amount.

The application of the preparations of amniotic membranes is much lower, since they are prescribed for less common surgical pathology and are used mainly in surgery. Hematopoietic stem cell drugs were prescribed less frequently, not only because of their high price, but also because of the complexity of their manufacturing.

The results of the analysis of data on clinical efficacy of MIBP use are shown in Table 2.

A positive effect was observed in $73.6 \%$ of patients, ranged from $61.2 \%$ (when using Platex Chorionic) to $92.3 \%$ (Cryocell-hemocells). In 90 patients (10\% of observations) the clinical effect was regarded as doubtful, in 34 patients $(3.8 \%)$ no effect was observed using conventional examination methods in accordance with current clinical protocols. In this case, one should take into account the possible error due to the fact that information on the MIBP effect on the course of the disease in $19.9 \%$ of patients was obtained in insufficient volume for analysis. 
Table 1: Quantitative distribution of medico-immunobiological products use in clinic

\begin{tabular}{lcccc}
\hline \multicolumn{1}{c}{ Medico-immunobiological product } & $\begin{array}{c}\text { Number } \\
\text { of doses }\end{array}$ & $\begin{array}{c}\text { Percentage } \\
\text { of doses (\%) }\end{array}$ & $\begin{array}{c}\text { Number } \\
\text { of patients }\end{array}$ & $\begin{array}{c}\text { Percentage } \\
\text { of patients }(\%)\end{array}$ \\
\hline Platex Amniotic Ophthalmic & 30 & 1.2 & 30 & 1.6 \\
Platex Amniotic & 125 & 4.8 & 125 & 6.6 \\
Platex Chorionic & 118 & 4.6 & 118 & 6.2 \\
Platex Chorional & 24 & 0.9 & 24 & 1.3 \\
Platex Placental & 1.223 & 47.4 & 1.223 & 64.7 \\
Cryocell-hemocells & 168 & 6.5 & 168 & 8.9 \\
Cryocell-hemocord & 81 & 3.1 & 40 & 2.1 \\
Cryocell-cryocord & 265 & 10.3 & 53 & 2.8 \\
Cryocell-cryoextract of placenta & 545 & 21.1 & 109 & 5.8 \\
Total & 2.579 & 100 & 1.890 & 100
\end{tabular}

Table 2: Overall efficacy of placenta-derived medico-immunobiological products application ( $n$ is the number of patients)

\begin{tabular}{|c|c|c|c|c|c|c|c|c|}
\hline \multirow[t]{2}{*}{ Medico-immunobiological product } & \multicolumn{2}{|c|}{$\begin{array}{c}\text { Positive } \\
\text { effect }\end{array}$} & \multicolumn{2}{|c|}{ Dubious effect } & \multicolumn{2}{|c|}{ No effect } & \multicolumn{2}{|c|}{$\begin{array}{l}\text { No information } \\
\text { available }\end{array}$} \\
\hline & $n$ & $\%$ & $n$ & $\%$ & $n$ & $\%$ & $n$ & $\%$ \\
\hline Platex Amniotic Ophthalmic & 21 & 70.0 & 4 & 13.3 & - & - & 5 & 16.7 \\
\hline Platex Amniotic & 90 & 72.0 & 12 & 9.6 & - & - & 23 & 18.4 \\
\hline Platex Chorionic & 72 & 61.0 & 9 & 7.6 & - & - & 37 & 31.4 \\
\hline Platex Chorional & 18 & 75.0 & 2 & 8.3 & 1 & 4.1 & 3 & 12.5 \\
\hline Platex Placental & 885 & 72.4 & 40 & 3.3 & 20 & 1.6 & 278 & 22.7 \\
\hline Cryocell-hemocells & 155 & 92.3 & 9 & 1.2 & 2 & 0.1 & 2 & 0.1 \\
\hline Cryocell-hemocord & 29 & 72.5 & 3 & 7.5 & 3 & 7.5 & 5 & 12.5 \\
\hline Cryocell-cryocord & 39 & 73.5 & 3 & 5.7 & 3 & 5.7 & 8 & 15.1 \\
\hline Cryocell-cryoextract of placenta & 81 & 74.3 & 8 & 7.3 & 5 & 4.6 & 15 & 13.8 \\
\hline Total & 1.390 & - & 90 & - & 34 & - & 376 & - \\
\hline
\end{tabular}

The obtained indices consist not only of the potential of biological effect of the drug, but also of the validity of medical prescribing, severity and curability of the disease.

Considering that we analyzed the MIBP effectiveness to treat the patients both with nosoological forms (as indicated for MIBP application) and correction of concomitant diseases, pathological conditions in which MIBP were used for, were combined into the following five groups: diseases of internal organs, nervous system, surgical or endocrine pathology, and obstetric-gynecological diseases. The distribution of patients according to placental MIBP application for various diseases and lesions is shown in the Figure.

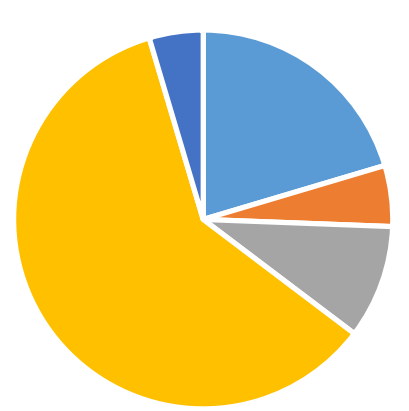

$$
\begin{aligned}
& \text { - Internal diseases } \\
& \text { - Diseases of the nervous } \\
& \text { system } \\
& \text { - Endocrine disorders } \\
& \text { - Obstetric and } \\
& \text { gynecological pathology } \\
& \text { - Surgical nosological } \\
& \text { pathology }
\end{aligned}
$$

Figure: Distribution of preparations used by nosological forms
When analyzing the effectiveness of using the placental MIBP according to different pathologies, it was revealed that the largest number of observations was carried out in the treatment of pathology of the female reproductive system and pregnancy. Among them, a significant group of patients made pregnant women with a disordered gestational process on the background of placental insufficiency. The effectiveness of MIBP used in obstetricgynecological pathology is explained by focusing the placenta biological effect to the processes of pregnancy and the female body (through the synthesis of primarily chorionic gonadotropin, alphafetoprotein and progesterone [2]), and the specifics of the institutions that used the products. The results obtained are consistent with research data on the biological effects of placental derivatives on experimental obstetric-gynecological pathology in both in vitro and in vivo models [7, 10-12].

With the use of placental MIBP in obstetric and gynecological practice, a significant clinical effect was achieved when correcting the following pathological conditions: pathology of pregnancy (miscarriage, chronic fetal hypoxia, gestosis, immunological conflict, threatening abortion), climacteric syndrome, infertility (including the prestage for IVF programs and in the protocols of 
pregravid preparation of women with antiphosiolipid syndrome and the complications by an obstetric history), disturbances of the ovarian-menstrual cycle. For pathology of pregnancy, the Platex Placental drug was used. In particular, 241 women with threatened abortion received Platex Placental against the background of standard treatment (antispasmodic, hormonal, vitamin therapy), which began to be used before the MIBP application. The standard treatment was ineffective, or some symptoms persisted. In 18 cases $(7.5 \%)$, miscarriage was diagnosed. After Platex Placental administration, the improvement of well-being and a decrease in the pain intensity in the lower abdomen were noted by women within the first week. The positive clinical effect during treatment was observed in 207 pregnant women $(85,9 \%)$, specificaly an increase in progesterone and chorionic gonadotropin levels, a decrease in the levels of antibodies and circulating immune complexes. Further inpatient treatment was needed for 23 pregnant women (9.5\%). Abortion was observed in 15 pregnant women $(6.2 \%)$. The most effective treatment was in pregnant women with hormonal disorders before pregnancy, the ones of the ovarian-menstrual cycle, or immunological disorders (allergic manifestations, antiphospholipid syndrome, Rh-conflict). Among the patients observed, in 198 women $(82.2 \%)$ the pregnancy resulted in physiological childbirth at 37-41 weeks. In general for the group of pregnant patients, 226 women $(93.8 \%)$ gave birth to living children in a satisfactory condition (7-10 points according to the Apgar scale).

Infertility treatment was carried out in 72 women, among which 41 women $(58.6 \%)$ received Platex Placental treatment, and 31 women (41.4\%) received Cryocell-cryoextract of placenta. Placental treatment was prescribed for the women with endocrine or immunological infertility. In their medical history the patients had the ovarian-menstrual irregularities or increased levels of antibodies (hemolysins, antiphospholipid antibodies), allergic manifestations, negative test contact. We did not treat the women with infertility due to obstruction of the fallopian tubes, or an increased level of prolactin, or other hypothalamic-pituitary hormones. The majority of women $(55(76.4 \%))$ received treatment with hormonal contraceptives without any effect (positive result in achieving regulation of the ovarian-menstrual cycle, but with no pregnancy onset). Of 72 women, 39 (54.2\%) became pregnant within a year after using the MIBP (among them, 22 women used the Platex Placental and 17 ones did the Cryocell-cryoextract of placenta).
During this period, 21 women were observed with disturbances of the ovarian-menstrual cycle. Among them, 15 patients (71.4\%) were with hypomenorrhea and 6 patients $(28.6 \%)$ with amenorrhea. Of these women, 17 received Cryocellcryoextract of placenta, and 4 received Platex Placental. The ovarian-menstrual cycle was completely restored in 11 women $(52.4 \%)$, in 7 patients (33.3\%) a partial restoration of the cycle was observed and in 3 patients $(14.3 \%)$ the treatment used was ineffective.

We obsereved 42 women with climacteric syndrome, among them $23(54.8 \%)$ received Platex Placental, and 19 (45.2\%) did the Cryocellcryoextract of placenta. All women ranged in age from 45 to 60 years, had climacteric syndrome of moderate (31 women (73.8\%)) or severe (11 women $(26.2 \%)$ ) degree. The main complaints were hot flashes, psycho-emotional disorders, dry mucous membranes, instability of blood pressure. After application of placental drugs, a decrease in hot flashes in all patients was observed. After treatment, 25 women $(59.5 \%)$ had mild climacteric syndrome, 5 women $(11.9 \%)$ did a moderate climacteric syndrome. As well, 12 women (23.8\%) previously suffered from pathological menopause fully recovered and did not experience the climacteric syndrome symptoms. The positive dynamics of hormonal profile and the correction of vasomotor and psychoemotional disorders in women with pathological menopause were revealed. The effect of therapy lasted for about a year in most patients. Five women (11.9\%) applied for repeated treatment and were re-treated after one year.

There were also 14 patients with chronic salpingo-oophoritis. All women underwent antibiotic therapy, and elimination of the pathogen was confirmed. Patients complained of chronic pelvic pain, menstrual irregularities and increased vaginal discharge, especially during the perimenstrual period and hypothermia. Nine patients $(64.3 \%)$ were treated with Platex Placental, and 5 patients (35.7\%) were treated with Cryocell-cryoextract of placenta. Complaints disappeared in 11 women $(78.6 \%)$ after treatment. Two women (14.3\%) still had problems with the ovarian-menstrual cycle (pain and irregularity). In most cases, the use of placental MIBP led to the normalization of immunogram parameters.

Thus, when using the placental MIBP in obstetric and gynecological practice, the strongest effect was observed in the pathology associated with immunological, dyscirculatory or endocrinological disorders, which coincides with the reported data [13-16]. 
Among the patients who received placental MIBP, a significant proportion had concomitant neurological pathology: astheno-neurotic syndrome, chronic fatigue syndrome, discirculatory encephalopathy, amyotrophic lateral sclerosis, consequences of cerebral palsy, encephalomyelitis, and myodystrophy. According to the literature data, the drugs of placental origin can be effective in nervous system pathology. The prophylactic and therapeutic effects of placenta products were determined in the model of glutamate excitotoxicity of neural cells in vitro and in an experimental model of discirculatory encephalopathy on the background of ovarian insufficiency in vivo $[14,17]$.

During the observation period, 104 patients with concomitant asthenovegetative syndrome and chronic fatigue syndrome underwent therapy. The main complaints of these patients were fast fatiguability (that did not pass after rest), depression, mood swings, sleep disorders, fluctuations in blood pressure. These patients underwent MIBP therapy, namely Cryocell-cryoextract of placenta, and Cryocell-cryocord. If a corresponding comorbid pathology was identified or in severe cases, Platex Placental and Cryocell-hemocord were prescribed. Patients were also recommended to undergo a vitamin therapy and physical activity, to change the mode of work and rest. After the treatment, complete regression of symptoms was observed in $67 \mathrm{pa}-$ tients $(64.4 \%)$, and partial regression was found in 27 patients (25.9\%). Patients showed normalization of sleep, stable positive mood, and significant improvements in efficiency. Fatigue, emotional disorders and sleep disturbances regressed most often. The repeated treatment was apllied by 35 women (33.6\%) (the effect of treatment in these patients persisted for one year). With repeated courses, the effect was longer, in average, up to 3 years.

There were observed 21 patients with different types of myodystrophies. The most common manifestations were muscle weakness and reflexes, weight loss, pathological changes in electromyography, in severe cases those were paresis, lack of control of urination and defecation. Standard basic therapy was performed in parallel. Complete remission was not achieved in any patient. Improvement according to clinical laboratory data was found in 25 patients $(80.6 \%)$, most often there was an increase in reflexes and muscle tone, two patients were able to control the act of defecation and urination. The therapy effectiveness was observed for 6-12 months. Repeated treatment was used for 14 patients, the effect of treatment after repeated courses was less lasting.
Among 43 patients with the consequences of infantile cerebral palsy, the patients with spastic and hemiplegic forms, often with delayed physical and mental development, prevailed. Most often, the patients were prescribed with Cryocell-cryoextract of placenta, Cryocell-cryocord, and Cryocell-hemocells. Improvements were noted in 28 patients $(65.1 \%)$, most of them applied for repeated treatment within two years. The effect after the second and third courses of treatment also improved the condition of the patients. With increasing age of patients, the effectiveness of treatment decreased.

Thirty-three patients with multiple sclerosis received Platex Placental or Cryocell-hemocells. The majority of patients showed a delay in the development of disease symptoms, 23 patients (69.7\%) experienced remission with regression of symptoms for up to $6-12$ months. Therapy was ineffective for 7 patients $(21.2 \%)$.

There were observed 31 patients with amyotrophic lateral sclerosis. Most of patients showed a slowdown in the progression of disease, the effect can be explained by the protective effect of drugs of placental origin against glutamate toxicity, which was shown later [12]. Cryocell-cryoextract of placenta, Cryocell-cryocord, and Cryocell-hemocells were prescribed. In a whole, the patients suffering from neurodegenerative diseases were observed in specialized medical institutions and received traditional treatment. However, addition to standard therapy by including placental MIBP led, in a significant number of observations, to a slowdown in the development of CNS damage, or to its suspension.

Among 17 patients with dyscirculatory encephalopathy the improvement of individual symptoms was observed in 14 patients (82.4\%). Cognitive, vestibular and autonomic disorders were corrected with the most significant result. Cryocellhemocells and Cryocell-cryocord were used for treatment. In addition, there is some data on the effectiveness of therapy with Cryocell-cryoextract of placenta and Cryocell-hemocells in Parkinson's disease (tremor reduction).

In general, analyzing the effectiveness of placental MIBP in neurological pathology, we can say that they are effective when the disease pathogenesis contains autoimmune, discirculatory, or degenerative components, which corresponds to sanogenesis and the general properties of this group of drugs.

Among endocrinological diseases, placental MIBP are most often used in Diabetes mellitus and its complications. A total of 108 patients were treated, $75(69.4 \%)$ are patients with type 2 diabetes, $33(30.6 \%)$ having type 1 diabetes. All the 
patients were diagnosed and received traditional therapy. In 62 patients $(57.4 \%)$, the diabetes complications were observed in the form of diabetic angiopathy, diabetic foot, neuropathy, and nephropathy. Depending on the severity and the disease course, the patients were prescribed with Platex Placental, Cryocell-cryocord or Cryocell-cryoextract of the placenta. For diabetic foot syndrome with ulcers, patients were bandaged with the Platex Chorial. The treatment has been found to be more effective in type 2 diabetes. At the beginning of treatment, a short-term increase $(2-5$ days $)$ in blood glucose levels by $10-20 \%$ was observed. This was followed by a long-term decrease of glucose and glycosylated hemoglobin levels by $25-30 \%$, lasted at least 6 months, and sometimes more than a year, which allowed to reduce doses of insulin and oral hypoglycemic drugs. The effectiveness of the treatment of diabetic foot syndrome increased by $23 \%$, which manifested in the healing of wounds and the possibility of further organ-sparing surgeries on the lower extremities in these patients. The effectiveness of diabetic retinopathy treatment was increased by $24 \%$.

\section{Application of placental MIBP in therapeutic practice}

In clinical practice of internal diseases, the placental MIBP were most often used for ischemic heart disease on the background of atherosclerotic vascular lesions. During the described period, 26 patients with coronary heart disease were treated. Platex Placental or Cryocell-cryoextract of placenta was prescribed, depending on the concomitant pathology and the disease severity. After the treatment we observed a decrease in the number of anginal attacks (which allowed to reduce the dose of nitrosorbide), and a decrease in the atherogenic coefficient according to the biochemical blood test. The clinical effect, which lasted up to 3 years, in addition to the subjective improvement of patients' quality of life, was accompanied by a gradual restoration of biochemical and electrophysiological correlates of the cardiovascular system.

\section{Application of placental MIBP in other patho- logies}

In addition to the mentioned pathological conditions, we observed the influence of placental preparations on the course of a number of diseases that do not imply the prescribing of such therapy, but were concomitant and there was a change in their clinical picture. Male infertility and impaired spermatogenesis were observed in 19 patients. In
13 men (68.4\%) there was an improvement in sperm and reproductive indices after application of Cryocell-cryoextract of placenta or Platex Placental. In one case, there was an exacerbation of chronic prostatitis, which was the result of improper treatment of the infectious process. In general, these preparations were effective in treating the effects of chronic prostatitis with obligatory preliminary elimination of infection, as proved in a previous study.

In the treatment of autoimmune pathological processes, an effect was obtained in the treatment of bronchial asthma (a decrease in the number of attacks and their duration). The data on the effectiveness in the treatment of rheumatoid arthritis have been obtained.

Effectiveness in the treatment of periodontitis has been observed in dental practice (with the local application of Cryocell-cryoextract of placenta).

The use of Platex Ophthalmic and Cryocellcryocord in ophthalmic practice in the pathology of the cornea and retina was effective, which evidenced both numerous experimental and clinical data $[13,18,19]$.

In surgical practice, the Platex Amniotic, Platex Chorional, Cryocell-cryocord and Cryocellcryoextract of placenta were used for the treatment of trophic ulcers. The therapy with the use of these preparations allowed to reduce the healing process. The use of Platex Chorional in the surgical treatment of trophic ulcers in the form of bandages allowed to reduce the duration of treatment and to prolong the recurrence-free period.

\section{Contraindications and side effects}

During the application of preparations, there was a rejection of the Platex Placental in three patients, which required its removal and drainage of the wound. One patient was intolerant to the Cryocell-hemocord by allergic reaction type, which required the administration of antihistamines. We observed one attack of bronchial asthma, which passed on its own, and two exacerbations of chronic infectious processes that required additional treatment. From experimental data it was known about the negative effect of the Cryocellcryoextract of placenta on the fetus, therefore, it was not prescribed during pregnancy [8].

\section{Discussion}

Regenerative medicine opens up new opportunities in the treatment of patients [6]. The source of biomaterial for it can be bone marrow, adipose 
tissue, placenta. The advantages of the placenta are harmless for donors, low immunogenicity, a large number of stem cells, and a variety of materials (tissues, cells, cord blood serum, membranes, extracts) $[2,20]$. Placental derivatives are used as a source of biostimulants, a plastic material for replacing tissues in surgical practice and as a source of stem cells [1-3]. Reduced immunogenicity is explained by a decrease in the expression of MHC class Ia (HLA-A, HLA-B, HLA-C), an increase in MHC Ib (HLA-E, HLA-F and HLA-G), synthesis of anti-inflammatory cytokines (IL-4, IL-5 , IL-9, IL-10 and IL-13), and a decrease in proinflammatory cytokines IL-2, IL-6, TNF, IF-gamma [2, 3].

The study shows that placental preparations were the most effective in obstetric and gynecological pathology. The effectiveness of MIBP used in obstetric-gynecological pathology is explained by the tropism of the placenta and membranes to the female reproductive system through the synthesis of primarily chorionic gonadotropin, alpha-fetoprotein and progesterone [2]. Thus, during pregnancy, after MIBP implantation, the functioning of the reproductive system changes first. The results obtained are consistent with research data, which also indicate the effectiveness of placenta and stem cell conditioned media, most notably in hormonal, dystrophic and autoimmune disorders of the reproductive system $[7,10,11]$.

The effectiveness of regenerative medicine methods in the treatment of neurological disorders is due to the proven neuroprotective effect, antioxidant, antiapoptotic and immunomodulatory effects of stem cells, or compounds synthesized by the placenta $[13,14,16,17,20]$. The synthesis of such factors as tissue inhibitor of metalloproteinases, vasoactive intestinal peptide, nerve growth factor, fibroblast growth factor, epidermal growth fac- tor, angiogenin, endostatin and others by placental cells has been proven [1-3]. Special attention, both in experimental studies and in clinic, was paid to improving the quality of life and anti-aging effect of placental preparations [4, 12].

It is traditional to use amniotic and chorionic membranes in ophthalmology and surgery, which combine plastic coating of the defect with the release of biostimulants and antibacterial factors that fasten healing [16, 17].

Among comorbid pathology, there was amelioration of signs associated with degenerative, autoimmune or endocrine functional disorders, which also led to an improvement in the quality of life of patients.

The application of placenta preparations in infectious pathology can be dangerous due to the general immunosuppressive effect of both the placenta and stem cells from other sources [1, 3, 15]. Another contraindication may malignant state, but this issue remains debatable, since the antitumor effect of placental stem cells has been proven [2].

\section{Conclusions}

Cryopreserved placenta preparations are effective when used in obstetric, gynecological, neurological, endocrinological and therapeutic practice. Their effect is primarily observed in diseases, which are accompanied by autoimmune reactions, hormonal disorders, dysplastic or degenerative processes (miscarriage, menopausal syndrome, infertility, diabetes, coronary heart disease, asthenovegetative syndrome, amyotrophic lateral sclerosis involutive changes). The restricted application of placenta preparations is infectious disease process without proper pathogen elimination.

\section{References}

[1] Brown C, McKee C, Bakshi S, Walker K, Hakman E, Halassy S, et al. Mesenchymal stem cells: cell therapy and regeneration potential. J Tissue Eng Regen Med. 2019 Sep;13(9):1738-55. DOI: 10.1002/term.2914

[2] Pogozhykh O, Prokopyuk V, Figueiredo C, Pogozhykh D. Placenta and placental derivatives in regenerative therapies: experimental studies, history, and prospects. Stem Cells Int. 2018 Jan 18;2018:4837930. DOI: 10.1155/2018/4837930

[3] Silini AR, Cargnoni A, Magatti M, Pianta S, Parolini O. The long path of human placenta, and its derivatives, in regenerative medicine. Front Bioeng Biotechnol. 2015 Oct;3(162). DOI: 10.3389/fbioe.2015.00162

[4] Moon PD, Kim KY, Rew KH, Kim HM, Jeong HJ. Anti-fatigue effects of porcine placenta and its amino acids in a behavioral test on mice. Can J Physiol Pharmacol. 2014 Sep;92(11):937-44. DOI: 10.1139/cjpp-2014-0068

[5] Perillo A, Bonanno G, Pierelli L, Rutella S, Scambia G, Mancuso S. Stem cells in gynecology and obstetrics. Panminerva Med. 2004 Mar;46(1):49-59.

[6] Pipino C, Shangaris P, Resca E, Zia S, Deprest J, Sebire NJ, et al. Placenta as a reservoir of stem cells: an underutilized resource? Br Med Bull. 2012 Nov;105(1):43-68. DOI: 10.1093/bmb/lds033 
[7] Prokopyuk VYu, Grischenko OV, Prokopyuk OV, Shevchenko NO, Falko OV, Storchak AV, et al. Effect of cryopreserved placental explants on female reproductive system under normal and pathological conditions (experimental study). Probl Cryobiol Cryomed. 2017 Sep;28(3):250-65. DOI: 10.15407/cryo27.03.250

[8] Grishchenko VI, Yurchenko TN, editors. Placenta: Cryopreservation, structure, properties, prospects for clinical application. Kharkiv: Borovin Publ.; 2011. 268 p.

[9] Goltsev AN, editor. Actual problems of cryobiology and cryomedicine. Kharkiv: Raider; 2012. p. 469-86.

[10] Kozub MM, Prokopyuk VYu, Skibina KP, Prokopyuk OV, Kozub NI. Comparison of various of tissue and cell therapy approaches when restoring ovarian, hepatic and kidney's function after chemotherapy-induced ovarian failure. Exp Oncol. 2017 Sep;39(3):181-5. DOI: 10.31768/2312-8852.2017.39(3):181-185

[11] Prokopiuk VYu. Influence of media conditioned by cryopreserved and fresh placental explants and cells on murine uterine and ovarian organotypic cultures. Probl Cryobiol Cryomed. 2018 Mar;28(2):139-50. DOI: 10.15407/cryo28.02.139

[12] Prokopyuk OS, Prokopyuk VYu, Pasieshvili NM, Chyzhevskiy VV, Trifonov VYu, Karpenko VG, et al. Implantation of cryopreserved human placental fragments restores prooxidant-antioxidant balance in experimental animals of late ontogeny. Cryobiol Cryomed. 2017;27(1):61-70. DOI: 10.15407/cryo27.01.061

[13] Pischiutta F, Sammali E, Parolini O, Carswell HVO, Zanier ER. Placenta-derived cells for acute brain injury. Cell Transplant. 2018 Jan;27(1):151-67. DOI: 10.1177/0963689717732992

[14] Prokopyuk VYu, Chub OV, Shevchenko MV, Prokopyuk OS. Placental stem cells, organotypic culture and human placenta extract have neuroprotective activity. Cell Organ Transplant. 2017 May;5(1):39-42. DOI: 10.22494/cot.v5i1.67

[15] Ringden O, Baygan A, Remberger M, Gustafsson B, Winiarski J, Khoein B, et al. Placenta-derived decidua stromal cells for treatment of severe acute graft-versus-host disease. Stem Cells Transl Med. 2018 Apr;7(4):325-31. DOI: 10.1002/sctm.17-0167

[16] Seo TB, Han IS, Yoon JH. Growth-promoting activity of Hominis Placenta extract on regenerating sciatic nerve. Acta Pharmacol Sin. 2006 Jan;27(1):50-8. DOI: 10.1111/j.1745-7254.2006.00252.x

[17] Musatova IB, Volina VV, Chub OV, Prokopyuk VYu, Prokopyuk OS. Effects of implantation of cryopreserved placental explants on the behavioral indices and morphological characteristics of the cerebral structures in senescent mice. Neurophysiology. 2017 Oct;49(5):363-71. DOI: 10.1007/s11062-018-9696-4

[18] Jirsova K, Jones GLA. Amniotic membrane in ophthalmology: properties, preparation, storage and indications for grafting a review. Cell Tissue Bank. 2017 Jun;18(2):193-204. DOI: 10.1007/s10561-017-9618-5

[19] Paolin A, Cogliati E, Trojan D, Griffoni C, Grassetto A, Elbadawy HM, et al. Amniotic membranes in ophthalmology: long term data on transplantation outcomes. Cell Tissue Bank. 2016 Mar;17(1):51-8. DOI: 10.1007/s10561-015-9520-y

[20] Samadi P, Saki S, Khoshinani HM, Sheykhhasan M. Therapeutic applications of mesenchymal stem cells: a comprehensive review. Curr Stem Cell Res Ther. 2020 Sep 14;15(1). DOI: 10.2174/1574888X15666200914142709

В.Ю. Прокопюк, В.Г. Карпенко, М.В. Шевченко, Р.А. Сафонов, Н.М. Пасієшвілі, В.В. Лазуренко, О.С. Прокопюк

\section{ДОСВІД КЛІНІЧНОГО ЗАСТОСУВАННЯ КРІОКОНСЕРВОВАНИХ ПРЕПАРАТІВ ПЛАЦЕНТАРНОГО ПОХОДЖЕННЯ: КЛІТИН, ТКАНИНИ, ОБОЛОНОК, ЕКСТРАКТУ ТА СИРОВАТКИ ПУПОВИННОЇ КРОВІ}

Проблематика. Плацента людини є перспективним джерелом біологічного матеріалу для регенеративної медицини. Це обумовлено насамперед доступністю достатньої кількості матеріалу, наявністю великої кількості стовбурових клітин, низькою імуногенністю, високим проліферативним потенціалом клітин. У багатьох дослідженнях доведено ефективність стовбурових клітин, їх лізатів, кондиційованих середовищ за різних патологічних станів. Більшість досліджень $є$ експериментальними або перебувають на різних фазах клінічних випробувань. У той же час в Україні $€$ досвід клінічного застосування кріоконсервованих медикоімунобіологічних препаратів плаценти, який може бути підґрунтям для подальшого використання плацентарного матеріалу.

Мета. Проведення критичного аналізу даних щодо ефективності та перспектив застосування кріоконсервованих препаратів плаценти в клінічній практиці (клітин, тканини, оболонок, екстракту, сироватки плацентарної крові).

Методика реалізації. Проаналізовано результати клінічного застосування 2579 медичних імунобіологічних препаратів Платекс і Кріоцелл, виготовлених із плаценти. Звертали увагу на ефективність, перебіг супутньої, коморбідної патології у пацієнтів, а також на наявність негативних реакцій та ускладнень. Підраховували кількість застосованих препаратів, кількість пацієнтів за нозологічними формами.

Результати. Проаналізовано досвід застосування медичних імунобіологічних препаратів плацентарного походження за акушерсько-гінекологічної, терапевтичної, неврологічної та ендокринологічної патології. Отримані дані зіставлені з результатами досліджень у відповідних модельних експериментах у системах in vitro та in vivo. Визначено позитивний вплив препаратів плаценти на перебіг невиношування вагітності, клімактеричного синдрому, непліддя, цукрового діабету, ішемічної хвороби серця, розсіяного склерозу, бічного аміотрофічного склерозу, трофічних виразок. Протипоказанням до застосування препаратів плаценти на сьогодні залишаються деякі злоякісні новоутворення, наявність інфекційного процесу без належної елімінації збудника.

Висновки. Кріоконсервовані препарати з плаценти є ефективними при застосуванні в акушерсько-гінекологічній, неврологічній, ендокринологічній і терапевтичній практиці. Їх ефект спостерігається передусім при захворюваннях, які супроводжуються автоімунними реакціями, гормональними порушеннями, диспластичними чи дегенеративними процесами. Обмеженням до застосування препаратів плаценти є наявність інфекційного процесу без належної елімінації збудника.

Ключові слова: клітинна терапія; тканинна терапія; плацента; біобанкінг; регенеративна медицина; стовбурові клітини. 
В.Ю. Прокопюк, В.Г. Карпенко, М.В. Шевченко, Р.А. Сафонов, Н.М. Пасиешвили, В.В. Лазуренко, О.С. Прокопюк

\section{ОПЫТ КЛИНИЧЕСКОГО ПРИМЕНЕНИЯ КРИОКОНСЕРВИРОВАННЫХ ПРЕПАРАТОВ ПЛАЦЕНТАРНОГО ПРОИСХОЖДЕНИЯ: КЛЕТОК, ТКАНИ, ОБОЛОЧЕК, ЭКСТРАКТА И СЫВОРОТКИ ПУПОВИННОЙ КРОВИ}

Проблематика. Плацента человека является перспективным источником биологического материала для регенеративной медицины. Это обусловлено прежде всего доступностью достаточного количества материала, наличием большого количества стволовых клеток, низкой иммуногенностью, высоким пролиферативным потенциалом клеток. Во многих исследованиях доказана эффективность стволовых клеток, их лизатов, кондиционированных сред при различных патологических состояниях. Большинство исследований являются экспериментальными либо находятся на разных фазах клинических испытаний. В то же время в Украине имеется опыт клинического применения криоконсервированных медико-иммунобиологических препаратов плаценты, который может быть основой для дальнейшего использования плацентарного материала.

Цель. Проведение критического анализа данных по эффрективности и перспективам применения криоконсервированных препаратов плаценты в клинической практике (клеток, ткани, оболочек, экстракта, сыворотки плацентарной крови).

Методика реализации. Проанализированы результаты клинического применения 2579 медицинских иммунобиологических препаратов Платекс и Криоцелл, изготовленных из плаценты. Обращали внимание на эффективность, ход сопутствующей, коморбидной патологии у пациентов, а также на наличие негативных реакций и осложнений. Подсчитывали количество использованных препаратов, количество пациентов по нозологическим формам.

Результаты. Проанализирован опыт применения медицинских иммунобиологических препаратов плацентарного происхождения при акушерско-гинекологической, терапевтической, неврологической и эндокринологической патологии. Полученные данные сопоставлены с результатами исследований в соответствующих модельных экспериментах в системах in vitro и in vivo. Определено положительное влияние препаратов плаценты на ход невынашивания беременности, климактерического синдрома, бесплодия, сахарного диабета, ишемической болезни сердца, рассеянного склероза, бокового амиотрофического склероза, трофических язв. Противопоказанием к применению препаратов плаценты в настоящее время остаются некоторые злокачественные новообразования, наличие инфекционного процесса без надлежащей элиминации возбудителя.

Выводы. Криоконсервированные препараты из плаценты эффективны при использовании в акушерско-гинекологической, неврологической, эндокринологической и терапевтической практике. Их эффект наблюдается прежде всего при заболеваниях, которые сопровождаются аутоиммунными реакциями, гормональными нарушениями, диспластическими или дегенеративными процессами. Ограничением к применению препаратов плаценты является наличие инфекционного процесса без надлежащей элиминации возбудителя.

Ключевые слова: клеточная терапия; тканевая терапия; плацента; биобанкинг; регенеративная медицина; стволовые клетки. 